\title{
Determination of Oral Health Status in Patients Admitted to a University Hospital: A Pilot Study
}

\author{
Üniversite Hastanesine Başvuran Hastaların A Ăız Sağlı̆̆ı Durumlarının \\ Belirlenmesi: Pilot Çalışma
}

Gökçen Akçiçek** ${ }^{l}$, Hatice Boyacioğlu Doğru', Nihal Avcu ${ }^{l}$

\begin{abstract}
Aim: Oral mucosa, tongue, dentition and bone are important parameters for oral and systemic health care. A wide variety of lesions and conditions, either harmless or harmful, can affect the oral cavity. Identification and treatment of these conditions are an important part of oral health care. The aim of this study was to evaluate the general oral health status, by assessing the prevalence and types of mucosal, tongue, dental and jaw lesions, in a group of patients. Materials and methods: This study was conducted in a group of 314 dental outpatients. Participants' oral mucosal, tongue, dental, jaw lesions and their locations were recorded. Data were analyzed using logistic regression analysis. Results: Three hundred and fourteen patients (40.1\% female, $59.9 \%$ male), 148 (47.1\%) of whom exhibited one or more mucosal lesions, $40(12.7 \%)$ tongue lesions, $242(77.1 \%)$ one or more acquired dental conditions, 61 (19.4\%) one or more dental anomalies, and $22(7.0 \%)$ bone manifestations in the jaws. The most commonly detected mucosal lesions were Fordyce's granules (20.1\%), linea alba buccalis $(16.9 \%)$, melanoplakia $(15.9 \%)$, and frictional keratosis $(2.5 \%)$. Fissured tongue $(8.0 \%)$, geographic tongue $(1.6 \%)$, lingual varicosity $(1.3 \%)$ and coated tongue $(1.3 \%)$ were the most commonly determined tongue lesions. The most commonly detected dental anomalies were hypodontia (6.1\%), microdontia (4.1\%), dilaceration (4.1\%), and enamel hypoplasia (2.5\%). Exostoses $(4.1 \%)$, enostoses $(1.0 \%)$ and fibro-osseous lesions $(1.0 \%)$ were the most commonly detected bone manifestations in the jaws. Conclusion: Oral mucosal and tongue lesions could be a sign of systemic diseases and also could form a base for oral cancers. In this study oral mucosal lesions and tongue lesions prevalence were high but fortunately all the detected conditions were harmless, benign conditions. This emphasizes the importance of familiarity, awareness, and differentiation of these lesions and conditions to avoid unnecessary treatments.
\end{abstract}

Key words: Oral health, oral mucosal lesions, tooth anomalies, tongue lesions

ÖZET

Amaç: Oral mukoza, dil, dentisyon ve çene kemikleri ağız ve genel sağlı̆̆ın önemli parametreleridir. Zararlı ve zararsız birçok lezyon ve durum oral kaviteyi etkileyebilir. Bu durumların tespit ve tedavileri ağız ve genel sağlığın önemli bir parçasıdır. Bu çalışmanın amacı, bir grup hastanın ağız sağlığı durumlarının mukoza, dil, diş ve çene lezyonlarının prevalans ve tipleri değerlendirilerek belirlenmesidir. Gereç ve yöntem: Bu çalışmaya diş hekimliği fakültesine başvuran 314 hasta katıldı. Katılımcıların oral mukoza, dil, diş ve çene kemiklerindeki lezyonlar ve bu lezyonların lokalizasyonları kaydedildi. Veriler lojistik regresyon modeli oluşturularak incelendi. Bulgular: Üç yüz on dört hastanın (\%40.1 kadın, \%59.9 erkek), 148'inde (\%47.1) bir veya birden fazla mukoza lezyonu, 40'ında (\%12.7) dil lezyonu, 242'sinde (\%77.1) kazanılmış bir veya birden fazla dental patoloji, 61'inde (\%19.4) bir veya birden fazla diş anomalisi ve 22'sinde (\%7.0) kemik lezyonu tespit edildi. En sık karşılaşılan mukoza lezyonları Fordyce's granülleri (\%20.1), linea alba bukkalis (\%16.9), melanoplaki (\%15.9) ve friksiyonel keratozis (\%2.5) olarak saptandı. Fissürlü dil (\%8.0), coğrafik dil (\%1.6), lingual varikositler (\%1.3) ve paslı dil $(\% 1.3)$ ise en sık tespit edilen dil lezyonlarıydı. En sık karşılaş1lan dental anomaliler hipodonti (\%6.1), mikrodonti (\%4.1), dilaserasyon (\%4.1) ve mine hipoplazisi (\%2.5) olarak tespit edildi. Ekzostoz (\%4.1), enostoz (\%1.0) ve fibro-osseözlezyonlar (\%1.0) ise en sik karşılaşılan kemik lezyonlarıydı. Sonuç: Oral mukoza ve dildeki lezyonlar sistemik bir hastalığın bulgusu olabileceği gibi oral kanserlere zemin de oluşturabilmektedirler. Bu çalışmada oral mukoza ve dil lezyonlarının prevalansı yüksek olmakla birlikte saptanan tüm durumların zararsız ve iyi huylu olduğu belirlendi. Elde edilen sonuçlar bu tarz lezyon ve durumların bilinmesi ve ayırıcı tanılarının yapılarak gereksiz tedavilerin önlenmesinin son derece önemli olduğunu vurgulamaktadır.

Anahtar kelimeler: Ağız sağlı̆̆ı, dil lezyonları, diş anomalisi, oral mukoza lezyonları

Received / Geliştarihi:04.09.2016, Accepted / Kabul tarihi:08.10.2016

${ }^{1}$ Hacettepe Üniversitesi Diş Hekimliği Fakültesi, Ağız, Diş ve Çene Radyolojisi Anabilim Dalı

*Address for Correspondence / Yazışma Adresi: Gökçen Akçiçek, Hacettepe Üniversitesi Diş Hekimliği Fakültesi, Ağız, Diş ve Çene Radyolojisi Anabilim Dalı, Ankara-TÜRKIYE, E-mail:gokcen.akcicek@hacettepe.edu.tr

Akçiçek G, Doğru HB, Avcu N. Determination of oral health status in patients admitted to a university hospital: a pilot study. TJFMPC, 2016;10(4): 196-

204. DOI: $10.21763 /$ tjfmpc. 271329 


\section{INTRODUCTION}

Oral health is an inseparable part of general health and an important part of every individual's quality of life. Oral mucosa, tongue, dentition and bone are important components for oral health. Oral mucosa serves as a protective barrier against various factors such as trauma, pathogens, and carcinogenic agents. A wide variety of lesions and conditions, either harmless or harmful, can affect the oral mucosa. Identification and treatment of these conditions are an important part of oral and also systemic health care. $^{1,2}$

Tongue is the most accessible organ of the oral cavity and it performs various functions such as taste, swallowing, speech, and general sensation. ${ }^{1,3}$ In many studies oral mucosal lesions (OMLs) included tongue lesions. ${ }^{4,5}$ In this study tongue lesions are evaluated separately from mucosal lesions.

Dentition is the essential part in total oral health care and is the main factor that makes patients to visit the dentist. Although acquired dental conditions are most common complaints brought to dentists by patients, diagnosis and treatment of dental anomalies are also important due to the disturbances they could create in maxillary and mandibular dental arch lengths and occlusions. ${ }^{6}$

While some bone manifestations of the jaws are usually benign, and there is rarely a reason for removal, some which are aggressive or malign in nature and need to be removed. It is important to make the differentiation of these lesions to avoid unnecessary surgery for benign lesions or delay in the treatment for malign lesions. ${ }^{7}$

Earlier epidemiologic studies of the oral health status of the general population in Turkey focused on specific topics such as lesions related to mucosa, tongue, dentition or bone seperately., ${ }^{3,46-11}$ The aim of this study was to evaluate the general oral health status, by assessing the prevalence and types of mucosal, tongue, dental and jaw lesions, in a group of patients. This information will serve as a baseline for future studies and could be useful not only in dentistry but also for family medicine and primary care education protocols to improve oral health status in this country.

\section{MATERIALS AND METHODS}

This study was conducted at the Hacettepe University Faculty of Dentistry Department of Dentomaxillofacial Radiology in a group of 314 adult patients. The study was approved by the Ethical Committee of the Hacettepe University, and it is in compliance with the Helsinki Declaration. All of the voluntary participants had given their informed consent. Age, gender and systemic conditions of the participants were also recorded. There were no exclusion criteria. The patients were examined by the same researchers (2 research assistants). The researchers were calibrated by a professor of dentomaxillofacial radiology for oral mucosa lesions, tongue lesions, acquired dental conditions, dental anomalies, and jaw pathologies. Throughout the study, the examinations were carried out separately but in situations when either examiner failed to reach a decisive opinion, the examiners discussed the particular case and established a consensus and included it in the study. Clinical and radiologic examinations were performed according to the patient's individual needs and lesions were diagnosed according to the WHO guidelines ${ }^{12}$, Color Atlas of Common Oral Diseases $^{1}$ and the Oral Radiology ${ }^{7}$. Type of the lesions and their locations were recorded. Recurrent aphthae and recurrent herpes were recorded if observed at the time of examination. The diagnosis was based on clinical and radiological examinations and histopathologic confirmation of the lesions was not used in this study. Periodontal and gingival diseases were not included in this study.

Data were analyzed using the Statistical Package for the Social Sciences for Windows 19.0 (SPSS Inc, Chicago, IL, USA) and logistic regression analysis was used. The differences smaller than $0.05 \quad(\mathrm{p}<0.05)$ was accepted as statistically significant.

\section{RESULTS}

The demographic characteristics and systemic conditions of the 314 patients $(40.1 \%$ female and $59.9 \%$ male) are shown in Table 1. The patients had various systemic conditions and the most commons were cardiovascular diseases (mainly hypertension $\mathrm{n}=40,12.7 \%$ ), allergies and thyroid dysfunctions.

Out of these 314 patients, there were 148 participants $(47.1 \%)$ who exhibited one or more mucosal lesions, 40 patients $(12.7 \%)$ with tongue 
lesions, 242 patients $(77.1 \%)$ showed one or more acquired dental conditions, 61 patients (19.4\%) had

\begin{tabular}{|c|c|c|}
\hline & Number (n) & Percentage $(\%)$ \\
\hline \multicolumn{3}{|l|}{ Gender } \\
\hline Male & 188 & 59.9 \\
\hline Female & 126 & 40.1 \\
\hline \multicolumn{3}{|l|}{ Age group } \\
\hline $18-30$ & 102 & 32.5 \\
\hline $31-40$ & 63 & 20.1 \\
\hline $41-50$ & 71 & 22.6 \\
\hline $51-60$ & 49 & 15.6 \\
\hline $61-70$ & 21 & 6.7 \\
\hline $71-80$ & 6 & 1.9 \\
\hline $81-90$ & 2 & 0.6 \\
\hline \multicolumn{3}{|l|}{ Systemic condition } \\
\hline Healthy & 177 & 56.4 \\
\hline Cardiovascular diseases & 62 & 19.7 \\
\hline Thyroid dysfunctions & 18 & 5.7 \\
\hline Allergies & 18 & 5.7 \\
\hline Neurologic-psychiatric disorders & 17 & 5.4 \\
\hline Lung diseases & 17 & 5.4 \\
\hline Musculoskeletal-connective tissue diseases & 15 & 4.8 \\
\hline Endocrine Diseases (Diabetes Mellitus) & 13 & 4.1 \\
\hline Sinusitis & 11 & 3.5 \\
\hline Gastrointestinal diseases & 11 & 3.5 \\
\hline Liver diseases & 10 & 3.2 \\
\hline Cancer & 7 & 2.2 \\
\hline Hematologic disorders & 5 & 1.6 \\
\hline Chronic renal failure & 2 & 0.6 \\
\hline Other & 3 & 0.9 \\
\hline
\end{tabular}

one or more dental anomalies, and 22 of them (7.0\%) diagnosed with bone manifestations in the jaws (Table 2).

The most commonly detected mucosal lesions were Fordyce's granules (20.1\%), linea alba buccalis $(16.9 \%)$, melanoplakia $(15.9 \%)$, and frictional keratosis $(2.5 \%)$. No malignant lesions were found in any participants. Localizations of the lesions are shown in Table 3. Although there was no significant relation between gender, age or systemic conditions and mucosal lesions ( $p>0.05)$, the prevalence of mucosal lesions was highest in the age group of 41-50 years.

Fissured tongue $(8.0 \%)$, geographic tongue $(1.6 \%)$, lingual varicosity $(1.3 \%)$ and coated tongue $(1.3 \%)$ were the most commonly determined tongue lesions. There was no significant relation between the tongue lesions and gender and systemic conditions $(p>0.05)$. There was a significant relation between the tongue lesions and the age groups of 51-60 and 61-70 years $(\mathrm{p}<0.05)$. The age groups of 51-60 and 61-70 had the highest risk for tongue lesions. Although the age group of 71-80 years had a high prevalence for tongue lesions this relation was not statistically significant ( $p>0.05$ ).

The most commonly detected acquired dental conditions were caries $(67.5 \%)$, periapical infections (17.5\%), pulp stones $(6.4 \%)$ and attritions $(5.7 \%)$. There was no significant relation among acquired dental conditions, age, gender and systemic conditions $(p>0.05)$. However, the age group of 61-70 years had the highest prevalence. 
The most commonly detected dental anomalies were hypodontia $(6.1 \%)$, microdontia $(4.1 \%)$, root dilaceration $(4.1 \%)$, and enamel hypoplasia $(2.5 \%)$. There was a significant relation between dental anomalies and gender, especially males had a lower risk for dental anomalies $(\mathrm{p}<0.05)$. Age had a significant relation with dental anomalies $(p<0.05)$ and the age group of $18-30$ years had the highest prevalence. There was no significant relation between dental anomalies and systemic conditions ( $\mathrm{p}>0.05)$.

Table 2. Types and percentages of the mucosal lesions, tongue lesions, acquired dental conditions, dental anomalies and bone manifestations of the jaws

\begin{tabular}{|c|c|c|}
\hline & Number (n) & Percentage (\%) \\
\hline Mucosal Lesions" & 148 & 47.1 \\
\hline Fordeyce's granules & 63 & 20.1 \\
\hline Linea alba buccalis & 53 & 16.9 \\
\hline Melanoplakia & 50 & 15.9 \\
\hline $\begin{array}{l}\text { Frictional keratosis } \\
\text { Others }{ }^{1}\end{array}$ & 8 & 2.5 \\
\hline Tongue Lesions & 40 & 12.7 \\
\hline Fissured tongue & 25 & 8.0 \\
\hline Geographic tongue & 5 & 1.6 \\
\hline Lingual varicosity & 4 & 1.3 \\
\hline $\begin{array}{l}\text { Coated tongue } \\
\text { Others }{ }^{2}\end{array}$ & 4 & 1.3 \\
\hline Acquired Dental Conditions" & 242 & 77.1 \\
\hline Caries & 212 & 67.5 \\
\hline Periapical infection & 55 & 17.5 \\
\hline Pulp stones & 20 & 6.4 \\
\hline $\begin{array}{l}\text { Attrition } \\
\text { Others }^{3}\end{array}$ & 18 & 5.7 \\
\hline Dental Anomalies ${ }^{*}$ & 61 & 19.4 \\
\hline Hypodontia & 19 & 6.1 \\
\hline Microdontia & 13 & 4.1 \\
\hline Dilaceration & 13 & 4.1 \\
\hline $\begin{array}{l}\text { Enamel hypoplasia } \\
\text { Others }{ }^{4}\end{array}$ & 8 & 2.5 \\
\hline Bone Manifestations of the Jaws & 22 & 7.0 \\
\hline Torus & 13 & 4.1 \\
\hline Enostoses & 5 & 1.6 \\
\hline Fibroosseous lesions & 3 & 1.0 \\
\hline Socket sclerosis & 1 & 0.3 \\
\hline
\end{tabular}

* sum of the subgroups was not equal to the total number of patients in this group because patients had one or more conditions together.

${ }^{1}$ aphthous ulcers $(n=8,2.5 \%)$, leukoedema $(n=7,2.2 \%)$, purpura $(n=6,1.9 \%)$, denture stomatitis $(n=6,1.9 \%)$, morsicato buccarum $(n=3,1.0 \%)$, lip pits $(n=3,1.0 \%)$, chemical burns $(n=2,0.6 \%)$, peripheral scar $(n=2$, $0.6 \%)$, epulis fissuratum $(n=2,0.6 \%)$, irritation fibroma $(n=1,0.3 \%)$, herpes labialis $(n=1,0.3 \%)$, angular cheilitis $(n=2,0.6 \%)$

${ }^{2}$ hairy tongue $(n=2,0.6 \%)$, crenated tongue $(n=1,0.3 \%)$

3 enamel cracks $(n=16,5.1 \%)$, abrasion $(n=15,4.8 \%)$, pulpitis $(n=7,2.2 \%)$, root resorption $(n=2,0.6 \%)$, hypercementosis $(n=1,0.3 \%)$

${ }^{4}$ hyperdontia $(n=4,1.3 \%)$, rotation $(n=3,1.0 \%)$, dens in dente $(n=3,1.0 \%)$, talon cusp $(n=2,0.6 \%)$, fusion/germination $(n=1$, 


\begin{tabular}{|l|l|l|l|}
\hline Table 3. Localizations of the mucosal lesions \\
\hline Mucosal lesions & Localization & Number (n) & Percentage (\%) \\
\hline Fordeyce's granules & Bilateral buccal mucosa & 43 & 68.3 \\
& Lips & 10 & 15.9 \\
& Bilateral buccal mucosa and & 6 & 9.5 \\
& lips & 3 & 4.8 \\
& Unilateral buccal mucosa & 1 & 1.6 \\
& Bilateral retromolar area & & \\
\hline Linea alba buccalis & Bilateral buccal mucosa & 46 & 86.8 \\
& Unilateral buccal mucosa & 7 & 13.2 \\
\hline Melanoplakia & Generalized & 33 & 66.0 \\
& Gingiva & 9 & 18.0 \\
& Bilateral buccal mucosa & 4 & 8.0 \\
& Unilateral buccal mucosa & 2 & 4.0 \\
& Lips & 1 & 2.0 \\
& Gingiva and labial mucosa & 1 & 2.0 \\
\hline Frictional keratosis & Unilateral buccal mucosa & 6 & 75.0 \\
& Gingiva & 2 & 25.0 \\
\hline
\end{tabular}

Exostoses $(4.1 \%)$, enostoses $(1.0 \%)$ and fibro-osseous lesions (1.0\%) were the most commonly detected bone manifestations in the jaws. Although the age group of 31-40 years had a high prevalence for bone manifestations in the jaws, there was no significant relation between the bone manifestations and age ( $p>0.05)$. There also was no relation among bone manifestation, gender and systemic conditions ( $p>0.05$ ).

\section{DISCUSSION}

In this study the oral health status was evaluated under the topics of mucosal lesions, tongue lesions, acquired dental conditions, dental anomalies and bone manifestations of the jaws. The prevalence of mucosal lesions, tongue lesions, acquired dental conditions, dental anomalies, and bone manifestations were $47.1 \%, 12.7 \%, 77.1 \%, 19.4 \%$, and $7.0 \%$ respectively.

There are several studies on the prevalence of oral mucosal lesions, some of which have examined only the existing OMLs found during clinical examination $^{11,13}$, while others evaluated the recurrent lesions also by questioning the subjects. ${ }^{14,15}$ In this study, oral mucosal lesions or conditions that are detected only during the clinical examination were recorded and evaluated. The prevalence of OMLs in general population globally varies significantly across different regions and countries, ranging from $10.8 \%$ to $83.6 \% .^{13,16}$ Prevalence values found in these studies were either similar $^{11,17,18}$, lower ${ }^{4,5,10,13,19}$ or higher ${ }^{14,20}$ than our study. These prominent variations may be as a result of differences in geographic, demographic characteristics of the population studied, methodology and clinical diagnostic criteria.

Fordeyce's granules, linea alba buccalis, melanoplakia and frictional keratosis were the most commonly detected mucosal lesions. This pattern was substantially in accordance with data reported by previous studies. ${ }^{4,5,11,14,18,20}$ Most of these lesions and conditions are harmless and no biopsy or treatment is needed. Thus, the practitioner should be able to diagnose and differentiate these lesions and conditions from those which are more serious and worrisome.

Most of the lesions and conditions were found on the buccal mucosa, gingiva and lips and these sites are similar with other studies. ${ }^{20,21}$ Ghanaei et al. $^{5}$ reported that the most frequently involved sites for oral mucosal lesions were tongue, gingiva and lips. These findings are different from our study as we investigated the oral mucosal and tongue lesions separately.

Although it was reported that the prevalence of oral mucosal lesions is higher in older patients than in younger ones ${ }^{13,15,16,20}$ in this study the mid-aged (41-50) group had the highest prevalence. Findings of Ghanaei et al. $^{5}$ are compatible with our results. Age is not the only factor correlating with oral lesions but also trauma, medications, oral and denture hygiene play important roles. ${ }^{15,16}$ Some oral mucosal lesions 
could be a sign of systemic diseases. ${ }^{1}$ However there was not any statistically significant relation between systemic diseases and oral mucosal lesions. This is in consistence with other studies. ${ }^{4}$ Most of the detected oral mucosal lesions were harmless and pseudopathologic ${ }^{22}$ conditions and this could be the reason for absence of any relation.

Although there are studies that examined only tongue lesions ${ }^{3,23}$, in many studies tongue lesions are included in oral mucosal lesions. ${ }^{5,13,21,20}$ In this study tongue lesions were evaluated separately and prevalence was found to be $12.7 \%$. This result is very similar with some studies ${ }^{5,11,21,23}$ but conflicts with the results of other studies. ${ }^{3,4}$ The most commonly detected tongue lesions (fissured tongue, geographic tongue, lingual varicosity and coated tongue) are in accordance with previous studies. ${ }^{4,5,11,14,17,23}$ There was a relation between the tongue lesions and age which is also consistent with other studies. ${ }^{3}$ With advancing age, the frequency of the personal dental hygiene practices could diminish or become inadequate as well as systemic diseases and drug usage could increase. ${ }^{2,24}$ All of these mentioned conditions could provide a basis for tongue lesions.

In this study caries was the most commonly detected acquired dental condition and prevalence was $67.5 \%$. The caries prevalence varies around the world. Hence, other than the similar results $^{25}$, there are lower ${ }^{26}$ or higher ${ }^{27}$ caries incidences than this study. Our results were lower than the previous Turkish studies. ${ }^{8,9}$ It was reported that caries prevalence was higher in younger patients. ${ }^{9}$ However in this study caries was higher in older patients. These findings are promising for community based caries prevention programs in Turkey. There was no relation between caries and gender and this was in accordance with other studies. $^{28,29}$ The second most commonly detected acquired dental condition was periapical infections (17.5\%) (apical ostitis), and our results were lower than the study of Pekiner et al. ${ }^{30}$ in which they distinctively examined paediatric patients.

Dental anomalies in tooth number, shape, structure, and position are often observed and they may be present with malocclusion, esthetic and functional problems. Hence, their clinical management is usually complicated. ${ }^{31}$ In this study the prevalence of dental anomalies was $19.4 \%$ and hypodontia, microdontia, dilaceration and enamel hypoplasia were the most commonly detected dental anomalies. These findings were in accordance with other studies ${ }^{32}$ however, in orthodontic patients a remarkably high rate of dental anomalies was reported. ${ }^{33}$ On the other hand a Turkish study that examined only peadiatric patients found lower dental anomaly prevalence than our results. ${ }^{30}$ Females were affected more than males however there are studies that mentioned there were no differences between the genders. ${ }^{6,32,33}$ Because of these different results a comprehensive countrywide study is needed. Although it was reported that there is no difference in dental anomalies in regard to age, ${ }^{33}$ in this study age had a significant relation with dental anomalies. These studies focused on younger populations and their age distributions were narrower than our study. In this study the age group of 18-30 years had the highest prevalence of dental anomalies and the prevalence was lower in older age groups. This may be result of the increased dental restorations and extractions with increasing age. There was no significant relation between dental anomalies and systemic condition.

Two or more dental anomalies can often be observed in the same patient ${ }^{7,34}$ and $1.9 \%$ of patients had two dental anomalies. As dental anomalies may complicate dental treatments, especially orthodontic ones, their presence should be thoroughly investigated during intra-oral and radiologic examinations and carefully considered during treatment planning. ${ }^{31}$

The prevalence of bone manifestations in the jaws was $7.0 \%$ and the most commonly detected lesions were exostoses $(4.1 \%)$, enostoses $(1.0 \%)$ and fibro-osseous lesions (1.0\%). To our knowledge, there are no studies that reported the prevalence of bone manifestations in the jaws. As our sample was small, the prevalence may be different for more comprehensive studies in the future. Both exostoses and enostoses are growths of normal new bone that sometimes occurs in characteristic locations. While the exostoses are localized protuberances arising from cortical bone, the enostoses are the internal counterparts of exostoses. Torus palatinus, torus mandibularis and torus maxillaris are the common forms of exostoses found in the oral cavity. ${ }^{7,35}$ Because of the limited study population, in this study all tori were categorized under the exostoses. Data on the prevalence of exostoses are inconsistent and 
controversial. Although relations between age and exostosis, and gender and exostosis have reported, ${ }^{35,36}$ some studies indicate an insignificant difference in prevalence between genders. ${ }^{37}$ In this study there wasn't any relation and the reason could be our limited study population. Both of exostoses and enostoses usually do not require treatment. However, due to the fear of cancer, patients have these removed. ${ }^{7,35}$ Therefore it is important to distinguish these conditions and avoid unnecessary biopsy or surgery.

In most cases the radiographic characteristics and clinical information are sufficient to make a diagnosis of fibro-osseous lesions without a biopsy. ${ }^{7,38,39}$ Fibro-osseous lesions represent a heterogeneous group of pathologic conditions characterized by the replacement of normal bone with a fibrous tissue that undergoes subsequent abnormal mineralization. ${ }^{39}$ The true prevalence of fibroosseous lesions is unknown, as the data derived from the reported studies directly depend on the source of the cases. Considering the relatively high incidence of fibro-osseous lesions it is important to diagnose these lesions properly.

Although the age group of 31-40 years had a higher prevalence for bone manifestations in the jaws there was no significant relation between the bone manifestations and age. Also, bone manifestations are not related with gender and systemic conditions.

We are aware of the limitations of our study. First of all, study population was limited because this study was planned as a pilot study. Secondly risk factors of lesions were not investigated. Habits like cigarette smoking, alcohol intake, black tea drinking, oral hygiene and nutritional status of the population and their relation with oral health status can be investigated in further studies.

All patients were advised about their individual oral and dental care needs.

\section{CONCLUSION}

The present manuscript is the first study to report the prevalence and types of mucosal, tongue, dental, jaw lesions and systemic diseases with one accord. As oral health is an inseparable part of general health, both dentists and physicians share common responsibilities for their patients. Oral mucosal and tongue lesions could be a sign of systemic diseases and also could form a base for oral cancers. In this study, prevalence of oral mucosal lesions and tongue lesions were high, but fortunately all the detected conditions were harmless and benign. This emphasizes the importance of familiarity, awareness, and differentiation of these lesions and conditions to avoid unnecessary diagnostic and treatment procedures.

This study has also provided baseline information about epidemiologic aspects of general oral health status that can be valuable not only in dentistry education but also in family medicine and primary care programs concentrating on oral health in the society. As this was a pilot study, publishing new and more comprehensive results is goaled.

\section{ACKNOWLEDGEMENT}

This study was presented in $17^{\text {th }}$ International Congress on Oral Pathology and Medicine, 25-30 May 2014, in İstanbul Turkey.

Conflict of interest: The authors declare that they have no conflict of interest.

\section{REFERENCES}

1. Langlais RP, Miller CS. Color atlas of common oral diseases. Malvern, PA: Lea \& Febiger; 1992. p.12-23, 34, 42-99.

2. Triantos D. Intra-oral findings and general health conditions among institutionalized and non-institutionalized elderly in Greece. J Oral Pathol Med 2005; 34: 577-582.

3. Avcu N, Kanli A. The prevalence of tongue lesions in 5150 Turkish dental outpatients. Oral Dis 2003; 9: 188-195.

4. Cebeci ARİ, Gülşahı A, Kamburoğlu K, Orhan BK, Öztaş B. Prevalence and distribution of oral mucosal lesions in an adult Turkish population. Med Oral Patol Oral Cir Bucal 2009; 14: E272-E277.

5. Ghanaei FM, Joukar F, Rabiei M, Dadashzadeh A, Valeshabad AK. Prevalence of oral mucosal lesions in an adult Iranian population. Iran Red Crescent Med J 2013; 15: 600-604.

6. Altug-Atac AT, Erdem D. Prevalence and distribution of dental anomalies in orthodontic patients. Am J Orthod Dentofacial Orthop 2007; 131: 510-514. 
7. White SC, Pharoah MJ. Oral Radiology Principles and Interpretation. $5^{\text {th }}$ ed. St. Louis, Missouri; 2004.p.330-383, 410-457, 485-515.

8. Gökalp S, Güçiz Doğan B, Tekçiçek $M$, Berberoğlu A, Ünlüer Ş. The oral health profile of adults and elderly, Turkey-2004. Hacettepe Diş Hek Fak Derg 2007; 4: 11-18.

9. Kulak-Özkan Y, Ozkan Y, Kazazoglu E, Arikan A. Dental caries prevalence, tooth brushing and periodontal status in 150 young people in İstanbul: A pilot study. Int Dent J 2001; 51: 451-456.

10. Parlak AH, Koybasi S, Yavuz T, Yesildal N, Anul H, Aydogan I, et al. Prevalence of oral lesions in 13- to 16-year-old students in Duzce, Turkey. Oral Dis 2006; 12: 553-558.

11. Mumcu G, Cimilli H, Sur H, Hayran O, Atalay T. Prevalence and distribution of oral lesions: a cross-sectional study in Turkey. Oral Dis 2005; 11: 81-87.

12. World Health Organization. Oral health surveys, basic methods $4^{\text {th }}$ ed. Geneva WHO 1997: p.32-33.

13. Feng J, Zhou Z, Shen X, Wang Y, Shi L, Wang $\mathrm{Y}$, et al. Prevalence and distribution of oral mucosal lesions: a cross-sectional study in Shanghai, China. J Oral Pathol Med 2015; 44: 490-494.

14. Kovac-Kavcic M, Skaleric U. The prevalence of oral mucosal lesions in a population in Ljubljana, Slovenia. J Oral Pathol Med 2000; 29: 331-335.

15. Reichart PA. Oral mucosal lesions in a representative cross-sectional study of aging Germans. Community Dent Oral Epidemiol 2000; 28: 390-398.

16. Jainkittivong A, Aneksuk V, Langlais RP. Oral mucosal conditions in eldery dental patients. Oral Dis 2002; 8: 218-223.

17. Mathew AL, Pai KM, Sholapurkar AA, Vengal $M$. The prevalence of oral mucosal lesions in Southern India. Indian J Dent Res 2008; 19: 99-103.

18. Sandeepa NC, Jaishankar HP, Sharath Chandra B, Abhinetra MS, Darshan DD, Deepika N. Prevalence of oral mucosal lesions among PreUniversity students of Kodava population in Coorg District. J Int Oral Health 2013; 5: 3541.

19. Çelik İ, Güngör K. Oral mucosal lesions. T Klin J Dent Sci 2004; 10: 11-15.

20. Ali M, Joseph B, Sundaram D. Prevalence of oral mucosal lesions in patients of the Kuwait University Dental Center. Saudi Dent J 2013; 25: 111-118.

21. Diaz-Canel AIM, Vallejo MJGP. Epidemiological study of oral mucosal pathology in patients of the Oviedo School of Stomatology. Med Oral 2002; 7: 4-9.
22. Ceylan C. Pseudopathologies and examination of the oral mucosa. Türkderm 2012; 46: 60-65.

23. Patil S, Kaswan S, Rahman F, Doni B. Prevalence of tongue lesions in the Indian population. J ClinExp Dent 2013; 5: e128e132.

24. Evren Akalin B, Uludamar A, Işeri U, Kulak Ozkan Y. The association between socioeconomic status, oral hygiene practice, denture stomatitis and oral status in eldery people living different residential homes. Archives of Gerodontology and Geriatrics 2011; 53: 252-257.

25. Tsanidou E, Nena E, Rossos A, Lendengolts Z, Nikolaidis C, Tselebonis A, et al. Caries prevalence and manganese and iron levels of drinking water in school children living in a rural/semi-urban region of North-Eastern Greece. Environ Health Prev Med 2015; 20: 404-409.

26. Paula JS, Ambrosano GMB, Mialhe FL. The impact of social determinants on schoolchildren's oral health in Brazil. Braz Oral Res 2015; 29: 1-9.

27. Al-Maweri SA, Al-Soneidar WA, Halboub ES. Oral lesions and dental status among institutionalized orphans in Yemen: A matched case-control study. Contemp Clin Dent 2014; 5: 81-84.

28. Shaffer JR, Leslie EJ, Feingold E, Govil M, McNeil DW, Crout RJ, et al. Caries experience differs between females and males across age groups in Northern Appalachia. Int J Dent 2015; 2015: 1-8. Doi: 10.1155/2015/938213.

29. Aydemir H, Koca Ceylan G. Dental health levels of the population lives in the middle part of Black Sea region. A Ü Diş Hek Fak Derg 1999; 9: 96-99.

30. Pekiner FN, Borahan MO, Gümrü B, Aytugar E. Rate of incidental findings of pathology and dental anomalies in paediatric patients: a radiographic study. MÜSBED 2011; 1: 112116.

31. Patil S, Doni B, Kaswan S, Rahman F. Prevalence of dental anomalies in Indian population. J Clin Exp Dent 2013; 5: e183e186.

32. Bekiroglu N, Mete S, Ozbay G, Yalcinkaya S, Kargul B. Evaluation of panoramic radiographs taken from 1056 Turkish children. Niger J Clin Pract 2015; 18: 8-12.

33. Uslu O, Akcam MO, Evirgen S, Cebeci I. Prevalence of dental anomalies in various malocclusions. Am J Orthod Dentofacial Orthop 2009; 135: 328-335.

34. Kırzıoğlu Z, Köseler Şentut T, Özay Ertürk MS, Karayılmaz H. Clinical features of hypodontia and associated dental anomalies: a retrospective study. Oral Dis 2005; 11: 399404. 
35. Loukas M, Hulsberg P, Tubbs RS, Kapos T, Wartmann CT, Shaffer K, et al. The tori of the mouth and ear: a review. Clin Anat 2013; 26: 953-960.

36. Sathya K, Kanneppady SK, Arishiya T. Prevalence and clinical characteristics of oral tori among outpatients in Northern Malaysia. J Oral Biol Craniofac Res 2012; 2: 15-19.

37. Yoshinaka M, Ikebe K, Furuya-Yoshinaka M, Maeda Y. Prevalence of torus mandibularis among a group of elderly Japanese and its relation with occlusal force. Gerodontology 2014; 31: 117-122.
38. Alsharif MJ, Sun ZJ, Chen XM, Wang SP, Zhao YF. Benign fibro-osseous lesions of the jaws: a study of 127 Chinese patients and review of the literature. Int J Surg Pathol 2009; 17: 122-134.

39. Netto JNS, Cerri JM, Miranda AMMA, Pires FR. Benign fibro-osseous lesions: clinicopathologic features from 143 cases diagnosed in an oral diagnosis setting. Oral Surg Oral Med Oral Pathol Oral Radiol 2013; 115: e56-e65. 